\title{
Synopsis of the genus Peperomia Ruiz \& Pav. (Piperaceae) in Roraima State, Brazil ${ }^{1}$
}

\author{
Aline Melo ${ }^{2,4}$, Elsie F. Guimarães ${ }^{3}$ and Marccus Alves ${ }^{2}$ \\ Received: 5.10.2015; accepted: 27.01.2016
}

\begin{abstract}
Synopsis of the genus Peperomia Ruiz \& Pav. (Piperaceae) in Roraima State, Brazil). Peperomia is the second most diverse genus of Piperaceae, with an estimated 1,600 species and a pantropical distribution. This work aims to present a taxonomic synopsis of the genus in the State of Roraima, in the extreme north of the Brazilian Amazon forest and belonging to the central-south portion of the Guayana Shield. Based on collecting expeditions and analysis of specimens in various herbaria, 23 taxa were recognized, with two new records for the State and one of them, a new record for Brazil. The taxa are differentiated mainly by phyllotaxis, shape and size of their leaves, in addition to habit and fruits. They have been found in areas of lowland, submontane, montane, tepui and floodplain (várzea) forests and mostly show a distribution restricted to the Neotropics. Some species in the state are presently known exclusively from Mount Roraima, and restricted to a few specimens.
\end{abstract}

Keywords: Amazon Forest, Guayana Shield, new records, Piperales, Tepui

RESUMO - (Sinopse do gênero Peperomia Ruiz \& Pav. (Piperaceae) no Estado de Roraima, Brasil). Peperomia Ruiz \& Pav. é o segundo gênero mais diverso de Piperaceae, com aproximadamente 1.600 especies que estão distribuídas na região pantropical. Este trabalho tem o objetivo de apresentar uma sinopse taxonômica do gênero no Estado de Roraima, extremo norte da Floresta Amazônica brasileira, pertencente ao centro-sul do Escudo da Guiana. Com base em expedições e análise de espécimens de vários herbários, foram reconhecidos 23 táxons, dois são novos registros no Estado e um deles é um novo registro para o Brasil. As espécies se diferenciam principalmente pela filotaxia, forma e tamanho das folhas, além do hábito e frutos. Os táxons foram encontrados em áreas de terras baixas, submontanas, montanas, tepui e planícies inundáveis (várzea) e na maioria possui distribuição Neotropical. Algumas espécies no Estado são conhecidas exclusivamente no Monte Roraima e restringidas a poucos espécimens.

Palavras-chave: Escudo das Guianas, Floresta Amazônica, novos registros, Piperales, Tepui

\section{Introduction}

The Piperaceae family has the largest number of species of the order Piperales. The order comprises four other families, among which Saururaceae is considered the sister group to Piperaceae (APG III 2009). The family includes about 3,600 species in five genera, with a pantropical distribution and its greatest diversity in the Neotropics (Arias et al. 2006, Quijano-Abril et al. 2006, Wanke et al. 2006, Samain et al. 2008). It is divided into three subfamilies, of which Piperoideae Arn., including Peperomia Ruiz \& Pav. and Piper L., comprises the core of Piperaceae (Wanke et al. 2006, Samain et al. 2008).
Peperomia has about 1,600 species, more than 3,000 published names and a pantropical distribution (Wanke et al. 2006). The genus possessed several circumscriptions and hierarchical categorizations, including a separate family (Peperomiaceae, according to Heywood 1978), genera currently placed in Peperomia such as Acrocarpidium Miq. and Tildenia Miq. (Yuncker 1974) and also several subgenera and sections (Dahlstedt 1900, Trelease 1930, Wanke et al. 2006). Recently, Frenzke et al. (2015) recognized 14 subgenera, using morphological characters, mainly morphology of the fruit.

For Brazil, Miquel (1852) recognized 57 species of Peperomia, and later Yuncker (1974) found 163

1. Parte da Dissertação de Mestrado da primeira Autora

2. Universidade Federal de Pernambuco, Laboratório de Morfo-Taxonomia Vegetal, Departamento de Botânica, Centro de Ciências Biológicas, Av. Prof. Moraes Rego, s/n, Cidade Universitária, 50670-901 Recife, PE, Brasil

3. Instituto de Pesquisa Jardim Botânico do Rio de Janeiro, 22460-030 Rio de Janeiro, RJ, Brasil

4. Corresponding author: aline_vmelo@yahoo.com.br 
species for the genus in the country, organized in five subgenera and distinguished mainly by the morphology of the fruit. In both works (Miquel 1852, Yuncker 1974), some of the names listed with an Amazonian distribution are currently synonymized. According to Guimarães et al. (2015), there are 55 species of Peperomia in the Brazilian Amazon, 31 of them are considered endemic, with some restricted to one state. Studies of this area in Brazil have been done only by Costa \& Callejas-Posada (1999) and CallejasPosada (2008a). For the extra-Brazilian Amazon, there are some checklists (Callejas-Posada 1999, Callejas-Posada et al. 2007, Callejas-Posada 2008b), and taxonomic treatments that include Peperomia (Martínez 1997, Görts-van Rijn 2002, Steyermark \& Callejas-Posada 2003, Nee 2004, Görts-van Rijn 2007).

The Amazon rainforest is the largest rain forest in the world, covering more than 6 million $\mathrm{km}^{2}$ and nine South American countries, where an estimated 40,000 plant species occur, $75 \%$ of which are endemic (Mittermier 2003, Silva et al. 2005). In Brazil, the Brazilian Amazon (also known as Amazônia Legal) comprises areas of nine states with a wide range of vegetation types from dense Ombrophylous Forests to Savannas (Veloso et al. 1991, IBGE 2005). Among the vegetation types found, there are tepui, which are areas above 1,000-1,200 $\mathrm{m}$ and located in the Guayana Shield (Huber 1988). In Brazil, prominent tepui include the Serra do Aracá and Pico da Neblina, in Amazonas State, Mount Roraima, Serra do Tepequém and Serra dos Surucucus, located in Roraima (Huber 1988).

The objective of this work is to present a taxonomic synopsis of the species of Peperomia found in an area of the extreme north of the Brazilian Amazon, for which collection effort and knowledge of its plant diversity have been lacking. The geographic distribution, habitat, identification key and illustrations of species are also included.

\section{Materials and methods}

The area selected for the study comprises the State of Roraima, in the extreme north of the Brazilian Amazon and belonging to the south-central portion of the Guayana Shield ( $1^{\circ} 18^{\prime} 48^{\prime \prime} \mathrm{S}-5^{\circ} 30^{\prime} 51^{\prime \prime} \mathrm{N}$, $\left.58^{\circ} 41^{\prime} 49^{\prime \prime} \mathrm{W}-64^{\circ} 34^{\prime} 33^{\prime \prime} \mathrm{W}\right)$, with a total area of $224,301.04 \mathrm{~km}^{2}$. It has a border with Venezuela and Guyana to the north and, to the south with the States of Amazonas and Pará (Reis et al. 2003).
It has various vegetation types, such as open and dense Ombrophylous Lowland Forests $(0-100 \mathrm{~m})$, Submontane Forests (100-600 m), Montane Forests (>600 m), Alluvial Forests of várzea and igapó, campinaranas, savannas and tepui (Huber 1988, Veloso et al. 1991, IBGE 2005).

The field trips were made from September 2011 to May 2013 in five areas: Estação Ecológica de Maracá, Parque Nacional do Viruá, Mount Roraima, Serra Grande and Serra do Tepequém (figure 1) including various vegetation types (figure 2 ). The specimens were handled with the usual botanical techniques (Mori et al. 1989), deposited at Herbarium INPA, with duplicates sent to the herbaria UFP and RB (acronyms according to Thiers 2014). The review of existing herbarium collections was done using the collections of the herbaria EAFM, HB, HUAM (Herbário da Universidade Federal do Amazonas), IAN, INPA, MG, MIRR, NY, R, RB and UFRR in addition to the online query of some holdings, specifically $\mathrm{B}, \mathrm{K}$ and US.

To aid in the identification and geographic distribution of taxa, the following resources were used: Trelease \& Yuncker (1950), Yuncker (1957, 1974), Görts-van Rijn (2002, 2007), Steyermark \& Callejas-Posada (2003), Callejas-Posada et al. (2007), Callejas-Posada (2008a,b) and Guimarães et al. (2015), in addition to the material collected and available in the herbaria consulted. Morphological terminology followed Hickey (1974) and Harris \& Harris (2001).

For the species examined, one voucher is cited per municipality or for its entire distribution when scarce. For additional material when necessary, one voucher per state was included. Specimens indicated as coming from Mount Roraima were analyzed and included in this work due to the imprecision of locality (triple border among Brazil, Guyana and Venezuela), and also because it is considered very likely that the taxa occur also on the Brazilian side of the border.

\section{Results}

A total of 23 taxa of Peperomia were recognized from the study area, with two new records for the State of Roraima and one of them is a new record for Brazil compared to Yuncker (1974) and Guimarães et al. (2015): P. lancifolia Hook. and P. macrostachya (Vahl) A. Dietr. Most of the taxa found occur in the Neotropics, some of them restricted to areas of higher elevation. There are records of taxa in 
lowland, montane, floodplain (várzea) forests, forested campinaranas and tepui.

Peperomia angustata Kunth, P. delascioi Steyerm. and $P$. reptans C. DC., although cited by Steyermark and Callejas-Posada (2003), Callejas-Posada et al. (2007) and Görts-van Rijn (2007) for the region of Mount Roraima, was neither located in the field nor in the herbaria consulted.

\section{Taxonomic treatment}

Peperomia Ruiz \& Pavon, Fl. peruv. prodr. 6. 1794.

Annual or perennial herbs, terrestrial, epiphytic or saxicolous, usually succulent; stems prostrate, erect or decumbent. Leaves alternate, opposite or verticillate, entire, glabrous or pubescent, with red, yellow, brown or black glandular dots, peltate or not, of different shapes and consistencies, palmately or pinnately veined, sessile or petiolate, petiole cylindrical, sulcate or alate. Inflorescences in spikes or racemes, solitary or no, erect or pendent, axillary, terminal or leafopposed, rachis glabrous, pilose or papillose. Flowers numerous, minute, hermaphroditic, loosely or densely disposed; floral bracts usually orbicular, peltate, glabrous or fimbriate; stamens 2, filaments short or long; stigma 1, sessile or stylose, apical or subapical. Fruits drupaceous, sessile or stipitate, globoid, ovoid, ellipsoid, cylindric or obovoid, pseudocupulate or not, apex rounded, oblique or rostrate, occasionally the beak forming an apical hook; papillose or not.

Key to the taxa of Peperomia in the State of Roraima

1. Leaves opposite or verticillate

2. Prostrate herbs 16. Peperomia quadrangularis

2. Erect or decumbent herbs

3. Leaves petiolate; petiole $\geq 0.5 \mathrm{~cm}$ long.

4. Leaves 1,5-2,6 cm long, densely pubescent 9. P. increscens

4. Leaves 4-8 cm long, sparcely pubescent 4. P. decipiens

3. Leaves sessile or short-petiolate; petiole $\leq 0.2 \mathrm{~cm}$ long.

5. Rachis pilose 22. P. tetraphylla

5. Rachis glabrous

6. Leaves oblong, 3-5 mm wide

6. P. galioides

6. Leaves rhomboid to elliptical, 5-10 mm wide

17. P. quaesita

1. Leaves alternate

7. Leaves peltate

8. P. hernandiifolia

7. Leaves not peltate

8. Plants covered with black dots (stems, petioles, leaves, rachises, pedicels, floral bracts and fruits) ....

7. P. glabella

8. Plants not covered by black dots, or when present, brown in color

9. Prostrate herbs

10. Leaves $>7 \mathrm{~cm}$ long, obovate; spike $>5 \mathrm{~cm}$ long

12. P. obtusifolia

10. Leaves $\leq 1.5 \mathrm{~cm}$ long, orbicular to deltoid or cordiform; spikes $\leq 3 \mathrm{~cm}$ long.

11. Leaves and stems pilose; leaves generally cordate to deltoid

19. P. serpens

11. Leaves and stems glabrous to hirsute; leaves generally orbicular 18. P. rotundifolia

9. Erect herbs

12. Petioles ciliate

5. P. elongata

12. Petioles eciliate

13. Leaf venation palmate

14. Leaves 6-8 cm long; petiole sulcate or alate

2. P. alata

14. Leaves $0.8-2.5 \mathrm{~cm}$ long; petiole cylindrical

15. Stems and leaves pilose; spikes 2-3, rarely solitary 23. P. trinervula

15. Stems and leaves glabrous; spikes always solitary 14. P. pellucida

13. Leaf venation pinnate or with only the midvein evident

16. Flowers congested on the spikes

17. Spikes erect 
18. Leaf apices acuminate and ciliate; spikes solitary 1.P. acuminata

18. Leaf apices acute and eciliate; spikes in pairs 10. P. lancifolia 17. Spikes pendulous 11. P. macrostachya

16. Flowers lax on the spikes

19. Leaves coriaceous when dry

19. Leaves membranaceous when dry

20. Leaves 1-3 $\times 0.7-2 \mathrm{~cm}$, short-petiolate $(2-5 \mathrm{~mm}$ long) 15. P. purpurinervis 20. Leaves 6-7.5 $\times 3-4.5 \mathrm{~cm}$, long-petiolate (15-25 mm long.) 3. P. alpina

21. Stems densely pilose, branched; fruits sessile and globoid 13. P. ouabianae

21 . Stems glabrous to sparsely pilose, not branched; fruits pedicellate and cylindrical 22. Herbs 5-8 cm tall, stems sparsely pilose 20. P. tenella

22. Herbs $10-15 \mathrm{~cm}$ tall, stems glabrous 21. P. tenuipes

1. Peperomia acuminata Ruiz \& Pavon, Fl. peruv. 1: 32.1798.

Figure 3a

Terrestrial herbs up to $40 \mathrm{~cm}$ tall, stems erect. This species can be differentiated from other species by the leaves with an acuminate apex, in addition to the long spikes (12-30 cm long.). It can be confused with $P$. alpina, however $P$. acuminata has membranaceous leaves when dried, the flowers are congested, the rachis is greenish when fresh and the fruits are not prolonged at the apex.

Distributed in Central America, West Indies, Colombia, Venezuela, Brazil, Peru, Ecuador and Bolivia (Steyermark \& Callejas-Posada 2003). In Brazil, the species occurs in mountainous areas of the Atlantic and Amazon Forests, where it can be found in the States of Acre, Amazonas and Roraima (Yuncker 1974, Guimarães et al. 2015). In Roraima, it is known only from the region of Mount Roraima, from about $2,100 \mathrm{~m}$ up to $2,700 \mathrm{~m}$.

Material examined: BRASIL. AmAzonAs: São Gabriel da Cachoeira, Cordilheira Pico da Neblina, Caminho para o Pico 31 de Março, 11-X-1977 (fl.), W.A. Rodrigues 9869 (INPA). [VENEZUELA. Bolívar: Mount Roraima] Roraima, XII-1909, Ule 8595 (MG, missing sample); 11-II-2013 (fl.), A. Melo 1111 (UFP).

2. Peperomia alata Ruiz \& Pavon, Fl. peruv. 1: 31. 1798.

Figures 3b-d

Epiphytic herbs up to $30 \mathrm{~cm}$ tall, stems erect. This species can be recognized by its leaves $(6.5-8 \times 1.8-2.3 \mathrm{~cm})$ which are membranaceous when dry, glabrous, elliptical to lanceolate, with an acute to attenuated apex, in addition to palmate venation; petiole alate throughout their extension; spikes solitary and fruits globose. Similar to P. blanda (Jacq.) Kunth, but can be differentiated by phyllotaxis, hairiness of the leaves and shape of the petiole.

It occurs from Mexico to Ecuador, Peru and Brazil (Steyermark \& Callejas-Posada 2003). In Brazil, it is cited for the Cerrado, Atlantic and Amazon Forests, in the States of Acre, Amazonas, Amapá and Roraima (Yuncker 1974, Guimarães et al. 2015). Here it was found in areas of lowland and Montane Forests and tepui.

Material examined: BRASIL. RoRAIMA: [Alto Alegre], Maitá Mountains, Indian trail Surucucu, 12-II-1971 (fl., fr.), G.T. Prance et al. 13644 (INPA, RB); Serra dos Surucucus, 27-X-1991 (fl.), S. Almeida \& M. Cordeiro 743 (MG); São João da Baliza: Reservatório de Jatapu, s.d. (fr.), E.S. Silva 3193 (MIRR).

Additional material examined: BRASIL. AmAzonas: [Barcelos], Pico Rondon, 4-II-1984 (fl., fr.), J.J. Pipoly et al. 6640 (INPA).

3. Peperomia alpina (Sw.) A. Dietr., Sp. pl. 1: 157. 1831.

Figures $3 \mathrm{e}-\mathrm{f}$

Terrestrial herbs up to $40 \mathrm{~cm}$ tall, stems erect. This species can be distinguished from others by its size, leaves $(6.4-7.5 \times 3-4.1 \mathrm{~cm})$ coriaceous when dry, glabrous, long-petiolate $(1.5-2.3 \mathrm{~cm})$; spikes paired or grouped in threes, and fruits globoid with a long slender apical beak that may be hooked at the tip. This species can be compared to P. acuminata, but can be differentiated by the lax flowers on the spike, the reddish to orangish rachis when fresh, in addition to the shape of the fruit.

Distributed in West Indies, Central America, Colombia, Venezuela and French Guiana (Steyermark \& Callejas-Posada 2003, Callejas-Posada et al. 2007). In Venezuela, the species occurs on tepui, such as on "Auyán", "Ilú" and Mount Roraima, the latter being 
the only record for Brazil (Yuncker 1974, Steyermark $\&$ Callejas-Posada 2003) in which the taxon was found from 2,100 $\mathrm{m}$ to approximately 2,400 $\mathrm{m}$. Burger (1971), Steyermark \& Callejas-Posada (2003) and Callejas-Posada (2008b) mentioned the occurrence of the species between 1,500 and 3,000 m, from Costa Rica and Venezuela, in mountains, tepui forests, as well as in the Andes Mountains.

Material examined: [VENEZUELA. BoLÍvAR: Mount Roraima] Roraima, XII-1909 (fr.), E.H.G. Ule 8594 (MG). VENEZUELA. Bolívar: Mount Roraima, 30-IX-1944, (fl.), J.A. Steyermark 58990 (NY).

4. Peperomia decipiens C. DC., Notizbl. Bot. Gart. Berlin-Dahlem. (Append.) 6(62): 493. 1917.

Terrestrial or saxicolous herbs up to $40 \mathrm{~cm}$ tall, stems erect and pubescent. This species can be differentiated by its opposite or verticillate, elliptical (or rarely obovate), sparcely pubescent leaves (4.1-8 $\times 1.7-2.9 \mathrm{~cm}$ long), palmately 3-5-nerved, 1.7 $2.9 \mathrm{~cm}$ long petiole, axillary or terminal spikes and globoid fruits.

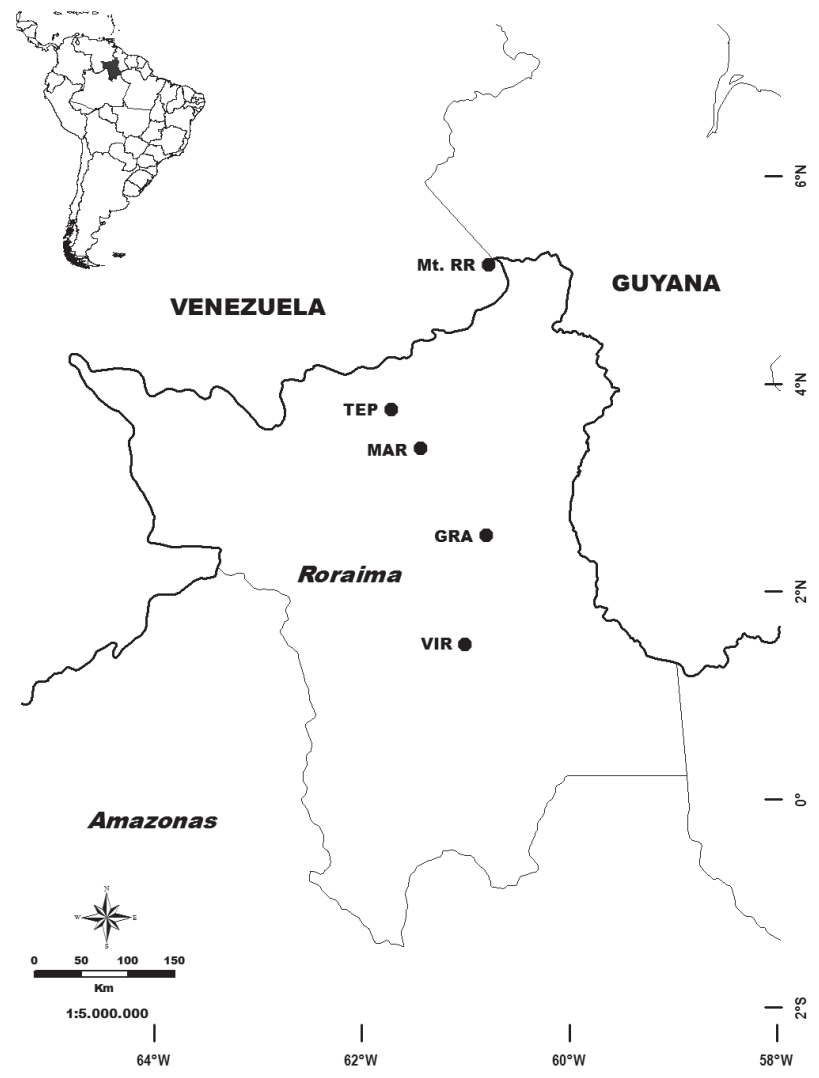

Figure 1. Visited areas. GRA- Serra Grande. MAR- Estação Ecológica de Maracá. Mt. RR- Mount Roraima. TEP- Serra do Tepequém. VIR- Parque Nacional do Viruá.
Endemic to Brazil (Yuncker 1974, Guimarães et al. 2015). It occurs in the Atlantic and Amazon Forests, in the states of Roraima, Ceará, Bahia and Minas Gerais (Guimarães et al. 2015). It was found in Montane Forest areas up to $700 \mathrm{~m}$.

Material examined: BRASIL. RoRAIMA: Pacaraima, Marco Divisor $\mathrm{n}^{\circ}$ 10, 4-IX-1979 (fr.), N.A. Rosa \& O.C. Nascimento 3270 (MG). Surumu, Serra do Mel, VII-1909 (fl.), E.H.G. Ule 8114 (MG).

5. Peperomia elongata Kunth in H. B. K., Nov. gen. sp. 1: 62.1815 [1816].

Figures 3g-h

Epiphytic herbs up to $30 \mathrm{~cm}$ tall, stems erect or decumbent. This species can be differentiated from other species by the glabrous, elliptical to lanceolate leaves (4-9.7 × 1.5-3.6 cm, rarely $2 \mathrm{~cm}$ long.), ciliated petiole and elliptical fruits [0.5-1.5 (2) $\mathrm{mm}$ long.]. It is similar to P. macrostachya (Vahl) A. Dietr., but can be distinguished by the size of the fruit, in addition to the ciliate petiole.

It occurs in Colombia, Venezuela, Guyana, Suriname, French Guiana and Brazil (Steyermark \& Callejas-Posada 2003). In Brazil, it occurs in Cerrado, Atlantic and Amazon Forests, from Roraima to Mato Grosso (Guimarães et al. 2015). Trelease \& Yuncker (1950) and Steyermark \& Callejas-Posada (2003) consider there to be three varieties of this species, distinguishable by the size of their leaves and hairiness. However, a strong overlap of characters was detected in the samples of the study area, thus it was not possible to use the proposed taxonomic varieties. The species was found in lowland and alluvial (várzea) forests.

Selected material examined: BRAZIL. RoRAIMA: [Alto Alegre], Ilha de Maracá, SEMA Ecological Reserve, Furo Santa Rosa, 23-III-1987 (fr.), W. Milliken 9 (INPA, MIRR); [Alto Alegre-Mucajaí], Rio Apiaú, 29-I-1967 (fl.), G.T. Prance et al. 4157 (INPA, MG, R, RB); [Amajari], Uaicá, Rio Uraricoeira, 2-II-1971 (fl.), G.T. Prance et al. 10825 (INPA, RB); Caracaraí, Parque Nacional do Viruá, Rio Anauá, 23-VIII-2012 (fr.), A. Melo et al. 1021 (INPA, UFP).

6. Peperomia galioides Kunth in H. B. K., Nov. gen. sp. 1: 62.1815 [1816].

Figure $3 \mathrm{i}$

Lithophytic or terrestrial herbs up to $50 \mathrm{~cm}$ tall, stems erect. This species can be differentiated from other species by having verticillate, sessile, oblong 

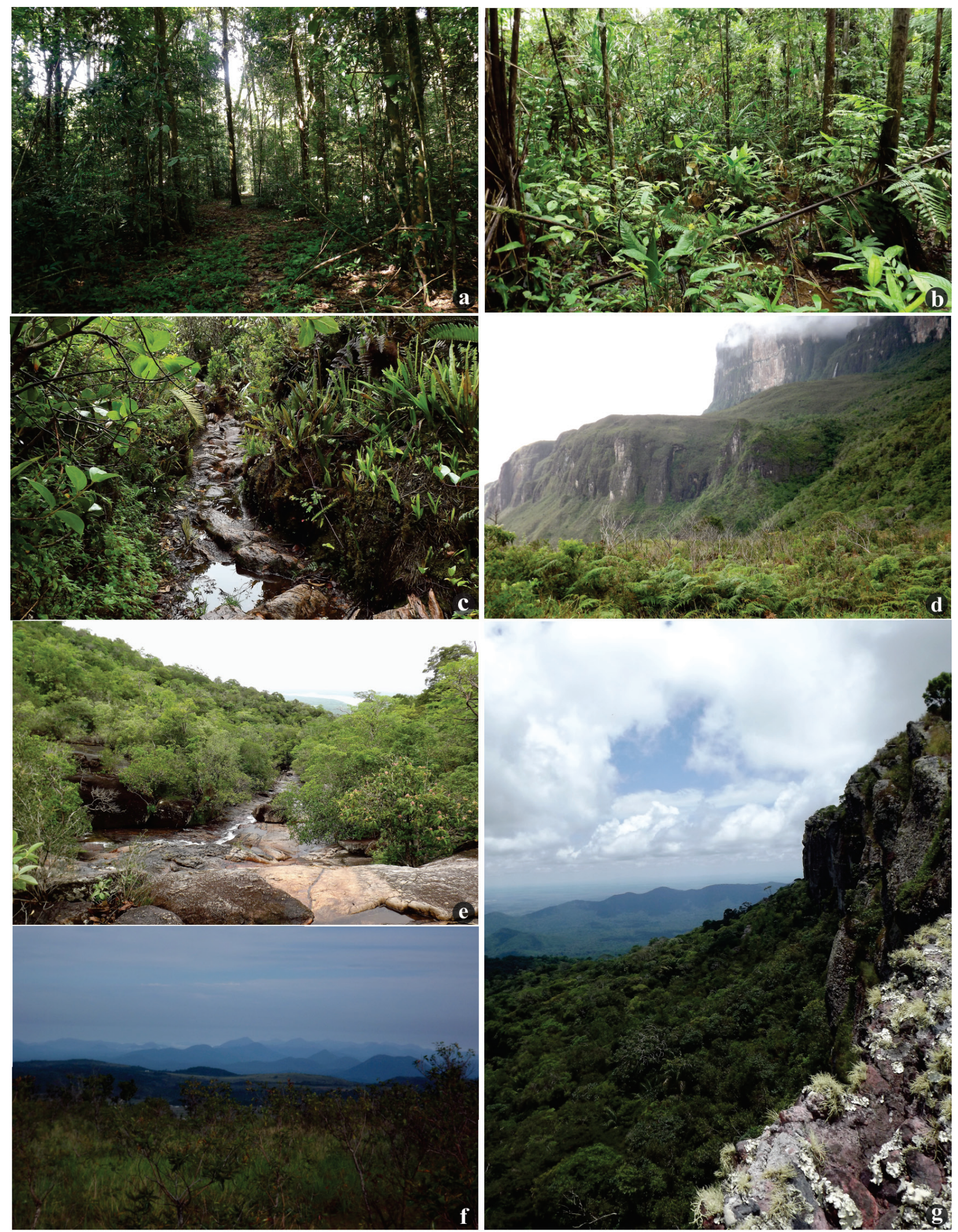

Figure 2. Visited areas. a. Estação Ecológica de Maracá (Ombrophylous Lowland Forest). b. Parque Nacional do Viruá (campinarana). c-d. Mount Roraima (tepui). c. Trail La rampa. d. Resting area on the base of the mountain. e. Serra Grande (Submontane Forest). f-g. Serra do Tepequém (tepui). f. View from the top of the major rocky formation. g. View of the northern side of the mountain facing the border with Venezuela. 
leaves $(5-11 \times 3-5 \mathrm{~mm})$, which are cuneate to rounded at the base, rounded to obtuse apex and globoid fruit.

Distributed from Mexico to South America (Steyermark \& Callejas-Posada 2003). In Brazil, it occurs in the Cerrado, Caatinga and Atlantic and Amazon Forests, generally in montane areas of over $1,000 \mathrm{~m}$ (Yuncker 1974, Guimarães et al. 2015). In the Brazilian Amazon, the species is registered only from Mount Roraima (Yuncker 1974), where it was found from approximately $2,100 \mathrm{~m}$ to $2,400 \mathrm{~m}$, in lightly shaded forest areas or open areas more exposed to sunlight.

Material examined: VENEZUELA. BoLÍvAR: Mount Roraima, 27-IX-1944 (fr.), J.A. Steyermark 58732 (NY); 26-VIII-2-IX-1976 (fl.), J.A. Steyermark 112585 (NY); 27-III-1984 (fr.), J.L. Luteyn \& G. Aymard 9768 (NY); 11-II-2013 (fr.), A. Melo 1109 (UFP).

Additional material examined: PERU. AmAzonAs: 43 kms of Balsas towards Leimebamba, 13-II-1985 (fl.), J.L. Luteyn \& E. Cotton 11311 (MG).

7. Peperomia glabella (Sw.) A. Dietr., Sp. pl. 1: 156. 1831.

Figure $3 \mathrm{j}$

Epiphytic herbs up to $30 \mathrm{~cm}$ tall, stems erect. This species is easy to distinguish from other species by the black dots present throughout the plant, in addition to the elliptical to lanceolate leaves $(1.5-7.4 \times 1-3 \mathrm{~cm})$, with palmate venation, axillary or terminal, arched spikes in number of the 2-3 or rarely solitary, and globoid fruits. It can be confused with $P$. alata, however the presence of black dots is distinct.

It occurs from Central America, West Indies and South America (Steyermark \& Callejas-Posada 2003). In Brazil, it occurs in the Atlantic and Amazon Forests, in the latter biome in the States of Roraima, Amapá, Amazonas, Pará and Acre (Guimarães et al. 2015). It is reported here for Rondônia. According to Steyermark and Callejas-Posada (2003), two varieties can be recognized based on the shape and size of the leaves, however this was not possible for the samples studied due to overlap of the proposed characters. The species is found in mountain and alluvial (várzea) forests.

Selected material examined: BRASIL. RoRAIMA: [Alto Alegre-Amajari], Ilha de Maracá, SEMA Ecological Reserve, 21-V-1987 (fl., fr.), W. Milliken \& S. Bowles 241 (INPA, MIRR); [Amajari], Auaris, 6-II-1969 (fl., fr.), G.T. Prance et al. 9640 (INPA, MG, R); Caracaraí,
Parque Nacional do Viruá, Rio Anauá, 31-VIII-2012 (fl., fr.), A. Melo et al. 1033 (INPA, UFP); [Iracema], Rio Repartimento, Fazenda Repartimento, 31-I-1984 (fl.), G.T. Prance et al. 28702 (INPA, RB); Mucajaí, Rio Mucajaí, 14-III-1971 (fl., fr.), G.T. Prance et al. 10958 (INPA, R); Rorainópolis, Rio Catrimani, 3-V-2011 (fl.), M. Carvalho-Silva \& A.E.R. Soares 1033 (UB, UFP).

Additional material examined: BRASIL. RondôNIA: Ouro Preto, BR 364, Km 353, 30-VI-1984 (fl.), C.A. Cid Ferreira et al. 4921 (INPA).

8. Peperomia hernandiifolia (Vahl) A. Dietr., Sp. pl. 1: 157.1831.

Figure 3k-1

Epiphytic herbs up to $10 \mathrm{~cm}$ tall, stems prostrate. It is easy to recognize for having peltate and alternate leaves $(4.5-7.4 \times 2.9-5.1 \mathrm{~cm})$, with long petioles (4-6 cm long), in addition to the solitary, axillary spikes and elliptical and papillose fruits.

Distributed in Mexico to Brazil (Steyermark \& Callejas-Posada 2003), where it is present in the Amazon Forest, in the States of Roraima and Amazonas, and in Atlantic Forest (Guimarães et al. 2015). In the study area, it was found in Montane Forests at 700-800 m, confirming the altitudinal range indicated by Trelease \& Yuncker (1950) for Venezuela.

Material examined: BRASIL. RoraIMA: [Alto Alegre], Serra dos Surucucus, 22-II-1969 (fr.), G.T. Prance et al. 10182 (INPA, MG, R, RB); [Amajari], Auaris, 6-II-1969 (fl.), G.T. Prance et al. 9642 (INPA, RB).

9. Peperomia increscens Miq., Linnaea 20: 124. 1847. Figure $3 \mathrm{~m}$

Epiphytic herbs up to $30 \mathrm{~cm}$ tall, stems erect. This species can be differentiated by its opposite or verticillate, elliptical to obovate, densely pubescent leaves $(1.5-2.7 \times 0.8-1.5)$, palmately $3-5$-nerved, $0.5-0.8 \mathrm{~cm}$ petiole, axillary or terminal spikes and globoid fruits.

Distributed in Argentina, Bolivia, Paraguay and Brazil (Zanotti et al. 2012). This species was found in Montane Forest area up to $700 \mathrm{~m}$ in the state of Roraima. Although Yuncker et al. (1974) and Guimarães et al. (2015) registered Peperomia increscens as synonym of Peperomia blanda (Jacq.) Kunth, Zanotti et al. (2012) kept the two species apart.

Material examined: BRASIL. [RoRAIMA] RIO BRANCO: [Pacaraima], Surumu, Serra do Mel, VIII-1909 (fl.), E.H.G. Ule 8113 (MG). 

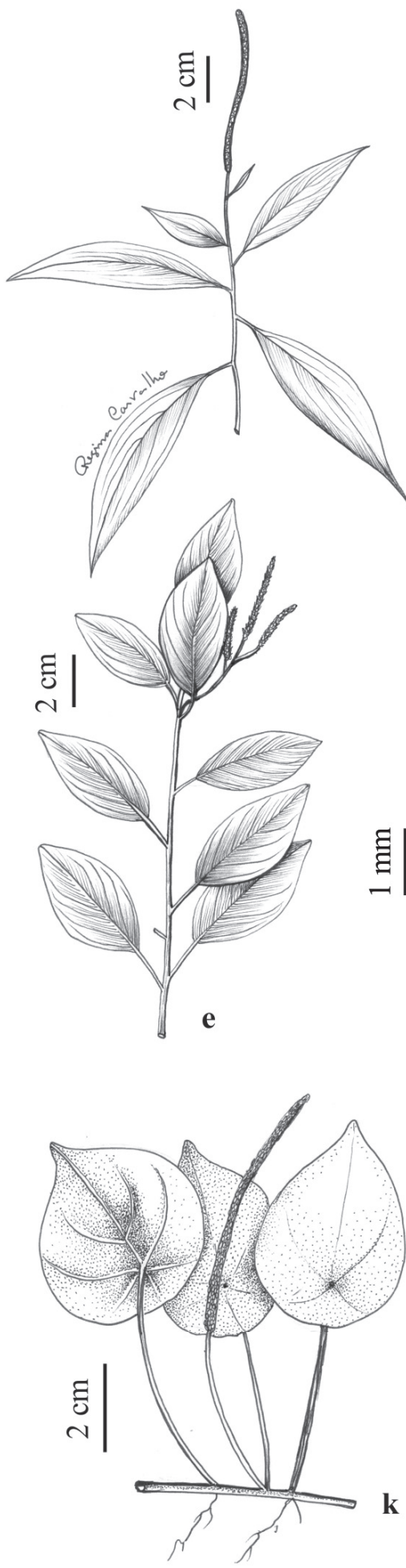
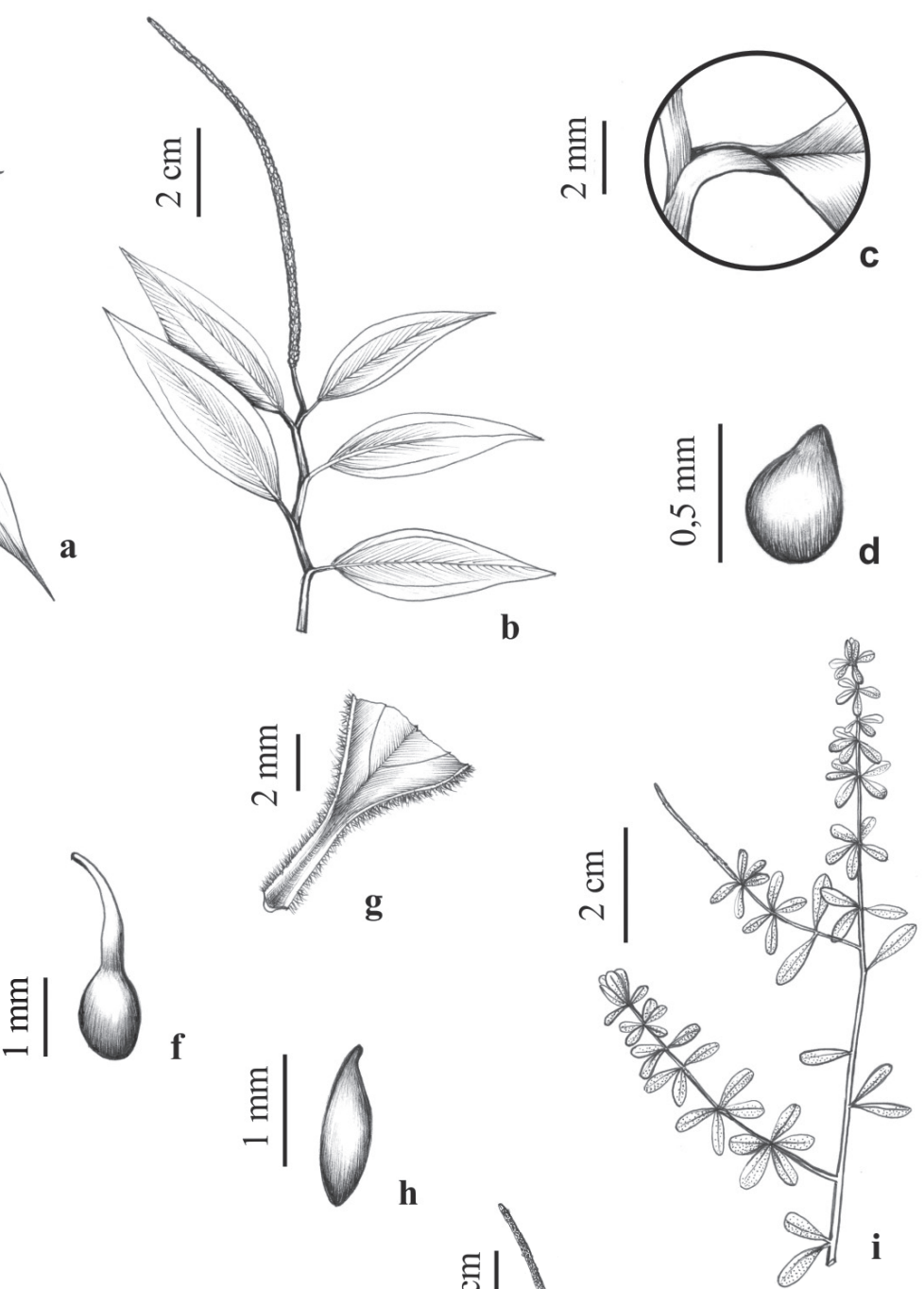

罗1

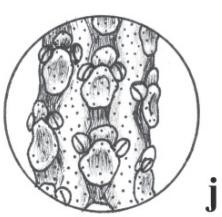

h
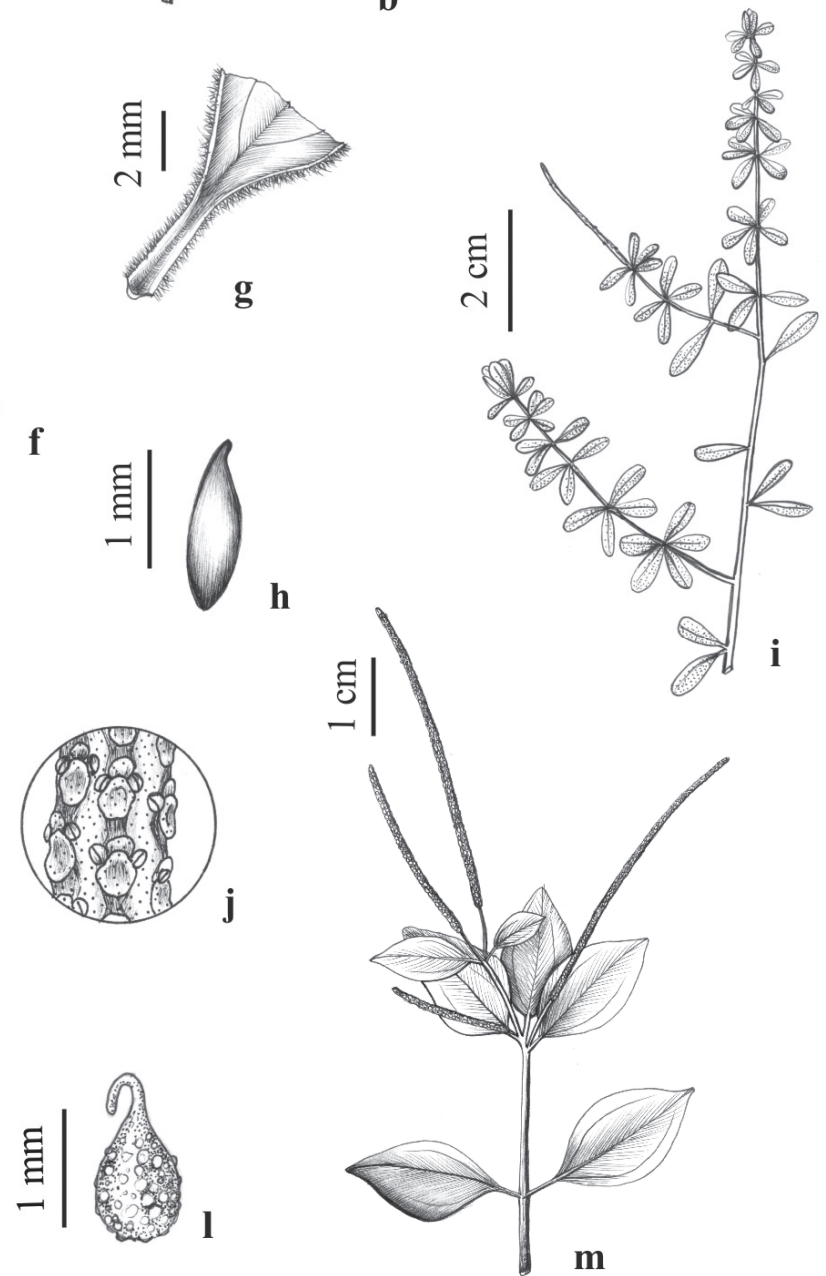

Figure 3. a. Peperomia acuminata Ruiz \& Pavon (W. Rodrigues 9869). Fertile stem. b-d. Peperomia alata Ruiz \& Pav. (G.T. Prance et al. 13644). b. Fertile stem. c. Detail of the petiole and base of leaf. d. Fruit. e-f. Peperomia alpina (Sw.) A. Dietr. (E.H.G. Ule 8594). e. Fertile stem. f. Fruit. g-h. Peperomia elongata Kunth. (W. Milliken 9). g. Detail of the petiole and base of leaf. h. Fruit. i. Peperomia galioides Kunth (A. Melo 1109). Fertile stem. j. Peperomia glabella (Sw.) A. Dietr. (E. Pessoa \& S.Vasconcelos 833). Detail of the spike with flowers, highlighting the glands over its entire structure. k-1. Peperomia hernandiifolia (Vahl) A. Dietr. (G.T. Prance et al. 10182). k. Habit. 1. Fruit. m. Peperomia increscens Miq. (E.H.G. Ule 8113). Fertile stem. 
10. Peperomia lancifolia Hook., Icon. pl. 4: t. 332. 1841.

Figures $4 a-b$

Terrestrial herbs up to $1 \mathrm{~m}$ tall, stems erect. It is distinct from other taxa based on its size, habit, stems with quite prominent nodes, leaves $(12-16 \times 1.5-2.5 \mathrm{~cm})$ with an attenuate base, attenuate to acuminate apex, paired spikes and elliptical fruits (1-1.5 mm long.). It is similar to P. acuminata, however $P$. lancifolia has leaves with an attenuate base, while $P$. acuminata has leaves with a rounded, obtuse to cuneate base and always solitary spikes.

It occurs in Mexico, Central America, Colombia, Venezuela, Guyana, Peru, Ecuador and Brazil (Steyermark \& Callejas-Posada 2003). Despite the previous authors citing the species for Brazil, Yuncker (1974) and Guimarães et al. (2015) did not mention it for the country. Its occurrence in Brazil is confirmed here. Despite the inaccuracy of locality indicated on collected specimens, it is believed to occur in Montane Forests, as has been cited for other countries (Trelease \& Yunker 1950, Steyermark \& Callejas-Posada 2003).

Material examined: BRASIL. RoRAIMA: Uiramutã, s.l., 18-IV-2007 (fr.), J. Batista 1569 (MIRR).

Additional material examined: GUYANA. CUYUNIMAZARUNI: South of Mount Ayanganna, 26-II-1987 (fl.), J.J. Pipoly et al. 10679 (MG).

\section{Peperomia macrostachya (Vahl) A. Dietr., Sp. pl.} 1:149. 1831.

Figures 4c-d

Epiphytic herbs up to $50 \mathrm{~cm}$ tall, stems decumbent. This species can be differentiated from other species by its elliptical to ovate leaves $(3.8-7.1 \times 1.8-4.3 \mathrm{~cm})$, with an attenuate to acute apex, sometimes with white patches on the adaxial surface, pinnate venation, eciliate petioles and cylindrical fruits (2-3.5 mm long.). While very similar to P. elongata, P. macrostachya has larger fruits and glabrous petioles.

Distributed from Mexico to Ecuador and Brazil, where it occurs in the Atlantic Forest and widely in the Amazon Forest (Steyermark \& Callejas-Posada 2003, Guimarães et al. 2015). The species is registered here for Roraima, where it was found in areas of lowland and Montane Forests.

Material examined: BRASIL. RoRAIma: Amajari, Serra do Tepequém, 1-IX-2012 (fr.), A. Melo et al. 1063 (UFP); Alto Alegre, Environs of the Maiongon village close to the FUNAI PIN Uaikas on the Alto Rio
Uraricoera, IX-1994 (fr.), W. Milliken 2150 (MIRR); Caracaraí, Estrada Boa Vista-Manaus, 3-V-1979 (fr.), I.A. Rodrigues et al. 882 (IAN); Mucajaí, Rio Mucajaí, 17-III-1971 (fr.), G.T. Prance et al. 11051 (INPA, RB); Rorainópolis, Rio Catrimani, Ponto 12, 13-II-1975 (fl.), J.M. Pires 15122 (IAN).

12. Peperomia obtusifolia (L.) A. Dietr., Sp. pl. 1: 154. 1831.

Figures $4 \mathrm{e}-\mathrm{f}$

Epiphytic herbs up to $15 \mathrm{~cm}$ tall, stems prostrate. This species can be differentiated from other species by its obovate to rarely elliptical leaves (7.5-11.5 × 4.1-4.8 cm), coriaceous when dried, with an obtuse, rounded or rarely emarginate apex, solitary, erect and axillary spikes and elliptical, papillose fruits with an extension at the apex which can form a hook. It can be confused with $P$. magnoliifolia (Jacq.) A. Dietr., which is not found in the study area, but has hirtose peduncles and petioles and larger and fruits (0.8-1 mm long.). Comparing it to the other species of the area, P. obtusifolia has leaves similar to P. alpina, but can be distinguished by its habit and the shape of the fruits.

Distributed from Mexico to South America (Steyermark \& Callejas-Posada 2003), and in Brazil is present in the Caatinga, Cerrado and Amazon and Atlantic Forests (Guimarães et al. 2015). In the Brazilian Amazon, it occurs in the States of Amapá, Pará and Roraima (Yuncker 1974, Guimarães et al. 2015), where it was found only in areas of Montane Forest. Although no records of the species exist for the State of Amazonas, it possibly occurs in montane areas of that State.

Material examined: BRASIL. Roraima: [Alto Alegre], Serra dos Surucucus, NE of Mission station, 17-II-1969 (fl.), G. T. Prance et al. 10008 (INPA, RB); [Pacaraima], Surumu, Serra de Mairary, IX-1909 (fr.), E.H.G. Ule 8381 (MG).

13. Peperomia ouabianae C. DC., Candollea 1: 400. 1923.

Figures 4g-h

Epiphytic herbs up to $6 \mathrm{~cm}$ tall, stems erect and pilose. It is characterized by its small size, elliptical to orbicular leaves (0.7-1.6 cm long) and globose and sessile drupes. It is similar to $P$. tenuipes, from which it differs by the hairiness of the leaves and stems and the shape of the fruits. It is comparable to P. rotundifolia, however these species differ in the shape of their leaves and the hairiness of the stems. 

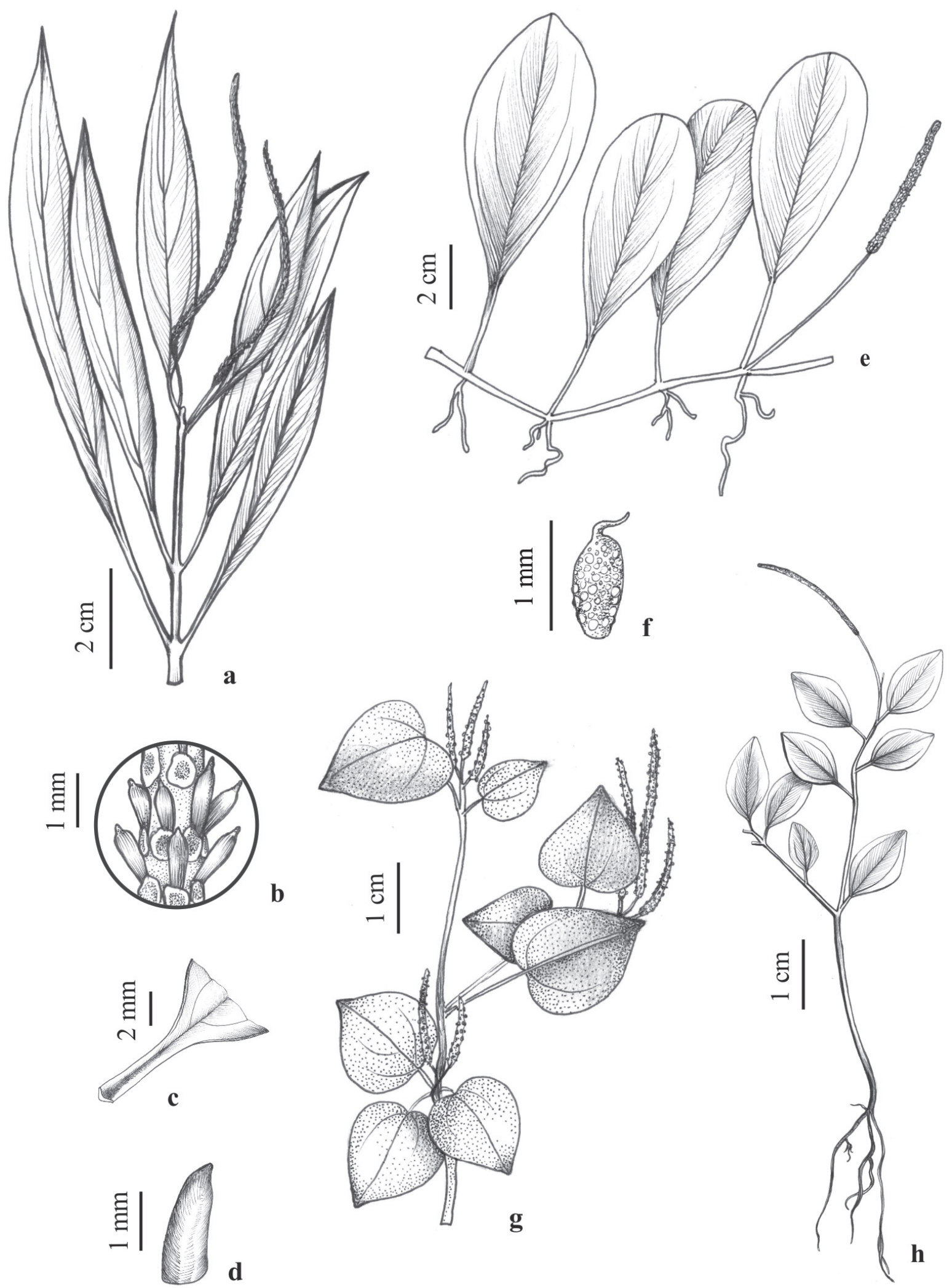

Figure 4. a-b. Peperomia lancifolia Hooker (J. Batista 1569). a. Fertile stem. b. Fruits. c-d. Peperomia macrostachya (Vahl) A. Dietr. (W. Milliken 289). c. Detail of the petiole and base of the leaf. d. Fruit. e-f. Peperomia obtusifolia (L.) A. Dietr. (E.H.G. Ule 8381). e. Habit. f. Fruit. g. Peperomia pellucida (L.) Kunth. (R.I. Barbosa 130). Fertile stem. h. Peperomia purpurinervis C. DC. (E.H.G. Ule 8592). Habit. 
It occurs in Nicaragua, Costa Rica, Colombia, Venezuela, Guyana, Suriname, French Guiana and Brazil, it has been recorded in the Atlantic and Amazon Forests (Görts-van Rijn 2007). It is found in Montane and Tepui Forests (760-2,000 m). P. pilicaulis C.DC. and $P$. ouabianae are not synonymy according Görtsvan Rijn (2007). These species are similar but differ in indument, leaf shape and size of fruit (Görts-van Rijn 2007).

Selected material examined: [VENEZUELA. BoLÍVAR: Mount Roraima] Roraima, II-1910 (fl.), E.H.G. Ule 8590 (MG, NY). BRASIL. Roraima: [Alto Alegre], Serra dos Surucucus, 18-II-1969 (fl.), G.T. Prance et al. 10064 (INPA, R, RB); [Amajari], Auaris, 6-II-1969 (fl.), G.T. Prance et al. 9630 (INPA, RB); Pacaraima, Vila Pacaraima, Marco BV-8, 19-X-1991 (fr.), S. Almeida \& M. Cordeiro 577 (MG).

14. Peperomia pellucida (L.) Kunth, Nov. gen. sp. 1: 64. 1815 [1816].

Figures $4 \mathrm{~g}$

Terrestrial herbs up to $50 \mathrm{~cm}$ tall, stems erect. This species can be differentiated from the other species by its habit, by being glabrous, with cordate to rarely deltoid leaves $(1-2.5 \times 1.5-2 \mathrm{~cm})$, with an acute apex, palmate venation and globoid fruits. From the shape of the leaves, it can be confused with $P$. serpens (Sw.) Loudon, but it can be distinguished as being terrestrial, usually short-petiolate (0.5-1.5 cm long.), as well as the shape of its fruits. The species can also be confused with $P$. trinervula C. DC., but it can be distinguished by the shape of its leaves and the coloration of the stem when fresh (greenish in P. pellucida and reddish in $P$. trinervula).

Pantropical (Trelease \& Yuncker 1950) and widely distributed in Brazil (Guimarães et al. 2015).

Material examined: BRASIL. Roraima: Boa Vista, Parque Anauá, 20-VII-2004 (fr.), R.I. Barbosa 130 (INPA); Paraviana, 4-I-2009 (fl., fr.), A.S. Flores et al. 2197 (MIRR).

Additional material examined: BRASIL. RoNDÔNIA: Santa Bárbara, Rodovia BR-364, Km 120, 28-V-1982 (fl.), L.O.A. Teixeira et al. 837 (INPA).

15. Peperomia purpurinervis C. DC., Notizblatt des Botanischen Gartens und Museums zu BerlinDahlem 6: 496. 1917.

Figure $4 \mathrm{~h}$

Epiphytic herbs up to $20 \mathrm{~cm}$ tall, stems erect. This species can be differentiated from other species by its size, the obovate, orbicular, oval to elliptical leaves [1.5-1.9 (2.6) $\times 0.7-1.4(1.9) \mathrm{cm}]$ that are coriaceous when dried, with an obtuse to rounded apex, and solitary, erect and terminal spikes (1.6-3.8 cm long.). Its leaves are similar to those of $P$. quadragularis, however this species can be distinguished by its habit and size, in addition to its phyllotaxis.

It occurs in Venezuela, French Guiana and Brazil, where it is known only from Mount Roraima and the state of Rio de Janeiro (Yuncker 1974, Steyermark \& Callejas-Posada 2003, Guimarães et al. 2015). According to Steyermark and CallejasPosada (2003) and Callejas-Posada (2008b), it occurs in the forests of tepui and mountain ranges between 1,200 and $2,000 \mathrm{~m}$.

Material examined: [VENEZUELA. BolívAR: Mount Roraima] Roraima, I-1910 (fl.), E.H.G. Ule 8592 (MG).

16. Peperomia quadrangularis (J.V. Thomps.) A. Dietr., Sp. pl. 1: 169. 1831.

Figure 5a

Epiphytic herbs, stems prostrate. It is distinguished from the other species by being prostrate, having quadrangular stems when dried, opposite or rarely 3-verticillate, ovate, orbicular to elliptic or obovate leaves, palmately 3-nerved, axillary spikes and globose fruits.

It occurs in the West Indies, Panama, Colombia, Venezuela, Guyana, Suriname, French Guiana and the Brazilian Amazon, in the States of Roraima, Amazonas and Pará (Steyermark \& Callejas-Posada 2003, Guimarães et al. 2015). One of the most common species of Peperomia recorded in herbaria visited and found in lowland, montane and alluvial (várzea) forests.

Selected material examined: BRASIL. RoRAIMA: Alto Alegre, Estação Ecológica de Maracá, 19-III-1987 (fl.), J.A. Ratter et al. 5783 (INPA, MIRR); [Alto Alegre-Mucajaí], Rio Apiaú, 30-I-1967 (fl.), G.T. Prance et al. 4183 (INPA, MG, RB); [Bonfim], Serra da Lua, 23-I-1969 (fl.), G.T. Prance et al. 9388 (INPA, R, RB); Caracaraí, Parque Nacional do Viruá, Rio Anauá, 31-VIII-2012 (fl.), A. Melo et al. 1030 (INPA, UFP).

17. Peperomia quaesita Trel., Publ. Field Mus. Nat. Hist., Bot. Ser. 13(2): 83. 1936.

Figure $5 b$

Epiphytic herbs up to $15 \mathrm{~cm}$ tall, erect and strigose stems. It is characterized by its rhomboid to rarely 

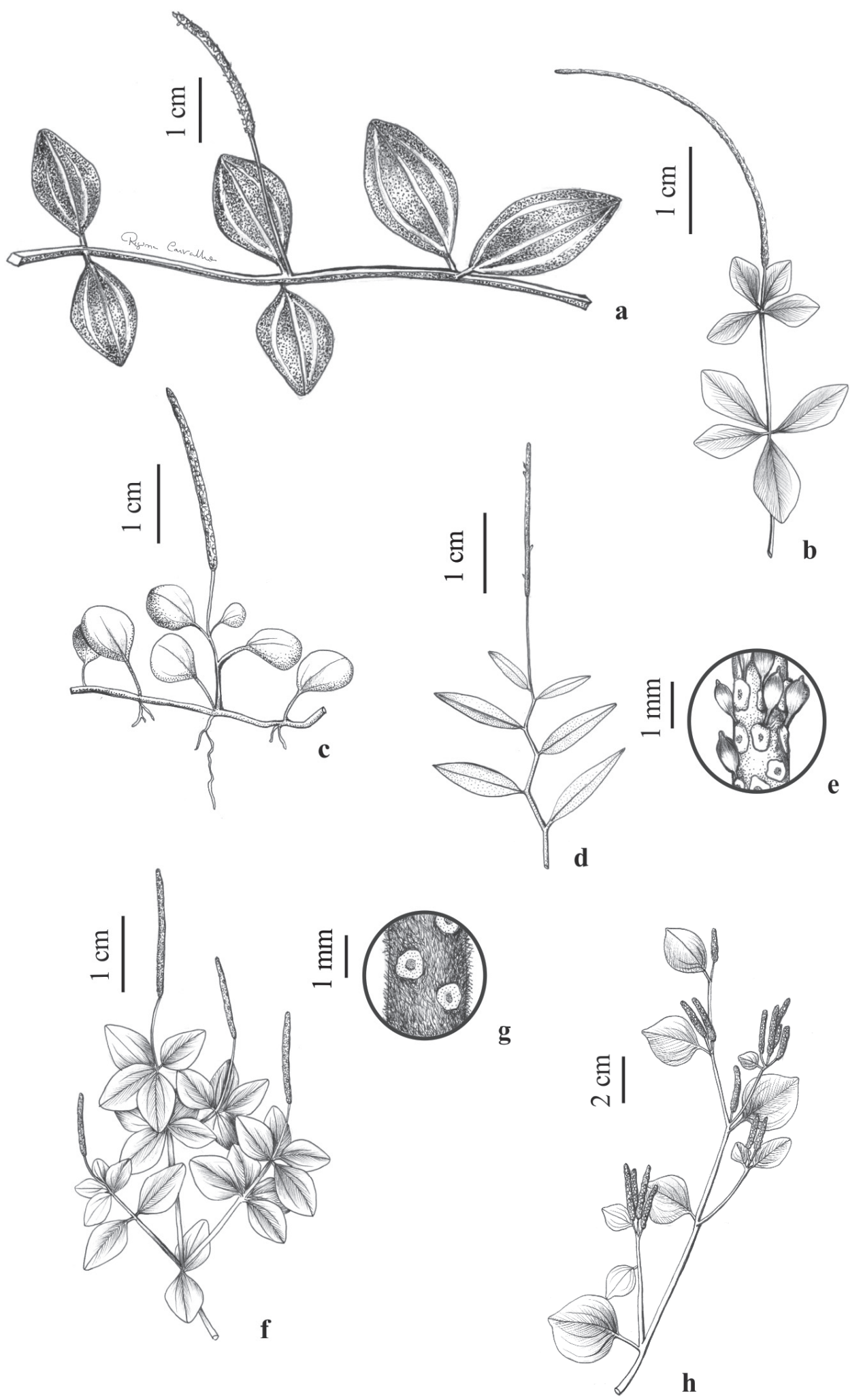

Figure 5. a. Peperomia quadrangularis (J.V. Thomps.) A. Dietr. (A. Melo et al. 1029). Habit. b. Peperomia quaesita Trel. (G.T. Prance et al. 13595). Fertile stem. c. Peperomia rotundifolia (L.) Kunth. (A. Melo et al. 1032). Habit. d-e. Peperomia tenella (Sw.) A. Dietr. (F.A. Carvalho et al. 334). f. Fertile stem. g. Fruits. f-g. Peperomia tetraphylla Hook. \& Arn. (E.H.G. Ule 8591). f. Fertile stem. g. Detail of the spike, highlighting the hairiness of the rachis. h. Peperomia trinervula (C. DC.) Steyerm. (E.H.G. Ule 8593). Fertile stem. 
elliptical leaves $(0.7-1.7 \times 0.4-0.8 \mathrm{~cm})$, with an acute apex and sessile to short-petiolate (up to $0.15 \mathrm{~mm}$ long.). The species can be confused with P. tetraphylla, but can be differentiated by the shape of the leaves, larger and thinner $(5-6 \times 0.1 \mathrm{~cm})$ spikes and glabrous rachis. It is also similar to Peperomia psilostachya C. DC. (which was not found in Roraima), but has a smaller $(0.8-1 \mathrm{~cm}$ long) peduncle, while in $P$. psilostachya, this exceeds $3 \mathrm{~cm}$ long.

It occurs in Venezuela, Colombia, Peru, Ecuador, Bolivia and Brazil, in which it has been cited for Acre, Amazonas and Roraima (Steyermark \& CallejasPosada 2003, Callejas-Posada 2008a, Guimarães et al. 2015). It was found in Montane Forests.

Material examined: BRASIL. RoRAIMA: [Alto Alegre], between Botamatatedi and Maitá, 10-II-1971 (fr.), G.T. Prance et al. 13595 (INPA); [Amajari], 6-II-1969 (fl.), G.T. Prance et al. 9673 (INPA, MG).

18. Peperomia rotundifolia (L.) Kunth, Nov. gen. sp. 1: 65-66. 1815 [1816].

Figure 5c

Epiphytic herbs with prostrate, glabrous to sparsely hirtose stems. This species differs from the others mainly by being delicate herbs with usually orbicular (rarely ovate, obovate to elliptical) leaves $(0.5-1.4 \times 0.4-1.1 \mathrm{~cm})$ and solitary and terminal spikes.

It occurs from Mexico to South America (Steyermark \& Callejas-Posada 2003), and in Brazil is present in the Atlantic and Amazon Forests, in the States of Roraima, Amazonas, Pará and Acre (Melo et al. 2014, Guimarães et al. 2015). In the study area, it was found in lowland, montane and alluvial (várzea) forests.

Selected material examined: BRASIL. RoRAIMA: [Alto Alegre], Serra dos Surucucus, 6-II-1971 (fl.), G.T. Prance et al. 13517 (INPA, RB); [Amajari], Uaicá, Rio Uraricoeira, 28-II-1971 (fl., fr.), G.T. Prance et al. 10772 (INPA, RB); Caracaraí, Parque Nacional do Viruá, Rio Barauana, 22-IX-2011 (fl.), A. Melo et al. 909 (INPA, UFP); Mucajaí, Rio Mucajaí, 14-III-1971 (fl.), G.T. Prance et al. 10959 (INPA).

19. Peperomia serpens (Sw.) Loudon, Hort. brit. 1: 13. 1830.

Epiphytic, pilose and brownish-dotted herbs, stems prostrate. It is easily recognized by its pilose, cordate to deltoid or rarely orbicular leaves $(0.9-1.5 \times 0.9-1.7 \mathrm{~cm})$ with an obtuse apex and longpetiolate $(0.6-3 \mathrm{~cm}$ long.). It can be confused with
P. urocarpa Fischer \& C.A. Meyer (which was not found in the study area), but in $P$. serpens leaves (0.9-1.5 cm long.) and spikes (0.9-1.5 cm long.) are smaller. Moreover, in $P$. serpens the position of the inflorescences is axillary, in P. urocarpa it is leaf opposed.

It occurs in Central America, West Indies and South America to Peru and Brazil (Steyermark \& Callejas-Posada 2003), where it is cited for the Atlantic and Amazon Forests, from Roraima to Mato Grosso (Guimarães et al.2015). It is one of the most common species of Peperomia in Roraima and be found in areas of montane and alluvial (várzea) forests.

Selected material examined: BRASIL. RoraIMA: [Alto Alegre], Serra dos Surucucus, 14-II-1971 (fl., fr.), G.T. Prance et al. 10518 (INPA, MG, RB); [Amajari], Uaicá, Rio Uraricoeira, 2-XII-1973 (fl.), G.T. Prance \& J.F. Ramos 19967 (INPA, RB); [Bonfim], $10 \mathrm{~km}$ SE of Serra da Lua, 17-I-1969 (fl.), G.T. Prance et al. 9315 (INPA, R); [Caracaraí-Rorainópolis], Rio Branco, Ponto 8A, 1-V-1974 (fl.), J.M. Pires et al. 14523 (IAN); Rorainópolis, Comunidade Xixuaú, 6-V-2011 (fl.), T. Marinho 218 (INPA); São João da Baliza, Reservatório de Jatapu, s.d. (fl.), E.S. Silva 3123 (MIRR).

20. Peperomia tenella (Sw.) A. Dietr., Sp. pl. 1: 153. 1831.

Figures 5d-e

Terrestrial herbs up to $8 \mathrm{~cm}$ tall. This species can be differentiated from other taxa mainly by being a delicate herb with small (6-12 $\times 3-6 \mathrm{~mm})$ and sparcely pubescent leaves, as well as the pedunculate fruits. It is very similar to $P$. tenuipes but that species is bigger and glabrous. It can also be confused with $P$. ouabianae, from which it can be differentiated by the shape of its leaves and fruits. Burger (1971) reported morphological similarity between $P$. tenella and $P$. tenuipes, treating them as a single taxon, while Steyermark \& Callejas-Posada (2003) considered them as: P. tenella var. tenella (Sw.) A. Dietr. and P. tenella var. tyleri (Trel.) Steyerm. Recently, Mathieu and Callejas-Posada (2006) treated them as separate species, differentiating them by height, branching and hairiness of the stems and leaves.

It occurs from Central America to Colombia, Venezuela and Brazil (Steyermark \& Callejas-Posada 2003, Guimarães et al. 2015). Although Guimarães et al. (2015) cite the occurrence of the species in Brazil for the Amazon (Amazonas) and Atlantic 
Forest (Minas Gerais, Rio de Janeiro, São Paulo, Santa Catarina and Paraná), it is also found in areas of the Amazonian tepui of the States of Amazonas and Roraima (De Candolle 1917, Prance \& Johnson 1992). In Roraima, the species has only been recorded from Mount Roraima, being abundantly found along the trail up to the top (between 1,900 and 2,300 m), in shaded sites, banks of waterfalls and rapids.

Material examined: BRASIL. AmAzonAs: Santa Isabel do Rio Negro, Parque Nacional Pico da Neblina, Trilha para a cachoeira do Anta, 29-XII-2004 (fl.), F.A. Carvalho et al. 334 (INPA). VENEZUELA. BolívAR: Monte Roraima, 13-II-2013 (fl.), A. Melo 1114 (UFP).

21. Peperomia tenuipes Trel., Contr. U.S. Natl. Herb. 26(4): 192. 1929.

Epiphytic herbs up to $10-15 \mathrm{~cm}$ tall, stems erect. It is characterized by its small $(0.8-2 \times 0.4-0.9 \mathrm{~cm})$, elliptical, rarely ovate to orbicular leaves with an obtuse apex, solitary and terminal spikes and cylindrical and long-pedunculate fruits.

It occurs in Honduras, Costa Rica, Venezuela, Colombia and Brazil, where it is known only from Mount Roraima (Yuncker 1974, Mathieu \& CallejasPosada 2006, Sutherland 2008, Callejas-Posada \& Patiño 2011, Guimarães et al. 2015). Yuncker (1974) and Guimarães et al. (2015) cite the occurrence for Roraima under the name of Peperomia tyleri Trel., currently considered synonymous with $P$. tenuipes Trel., according to Mathieu \& Callejas-Posada (2006). In Venezuela and Colombia, it is also cited for mountains and tepui between 600-2,600 m (Trelease \& Yuncker 1950, Steyermark \& Callejas-Posada 2003, Callejas-Posada 2008b).

Material examined: [VENEZUELA. BoLÍvAR: Mount Roraima] Roraima, I-1910 (fl.), E.H.G. Ule 8589 (MG).

22. Peperomia tetraphylla Hook. \& Arn., Bot. Beechey Voy 97. 1832 [1841].

Figures 5f-g

Epiphytic herbs up to $20 \mathrm{~cm}$ tall, stems erect. This species can be differentiated from other taxa by having verticillate, elliptical to ovate leaves $(0.8-1.5 \times 0.6-0.9 \mathrm{~cm})$, short-petiolate (up to $2 \mathrm{~mm}$ long.), in addition to solitary, erect and terminals spikes, 1.5-2 mm thick and hairy rachises. It can be confused with $P$. quaesita, but differs by the shape of the leaves and hairiness of the rachis. Yuncker (1974) proposed varieties for $P$. tetraphylla, based on the hairiness of stems and leaves and size of leaves, unlike Steyermark \& Callejas-Posada (2003) who considered these as part of the natural plasticity of the taxon.

Pantropical (Steyermark \& Callejas-Posada 2003). In Brazil, it is represented in the Caatinga, Cerrado, Atlantic and Amazon Forests, in the latter it is known only from Mount Roraima (Trelease \& Yuncker 1950, Yuncker 1974, Steyermark \& CallejasPosada 2003). According to Guimarães \& Giordano (2004) and Monteiro \& Guimarães (2008), the species occurs in montane areas of Ceará (Serra do Baturité) and high-montane forests of Rio de Janeiro (Parque Nacional do Itatiaia), respectively. The habitat of the study area is consistent with indications of Trelease \& Yuncker (1950) and Steyermark \& Callejas-Posada (2003), for Colombia and Venezuela, where the species can be found in areas of tepui and mountain ranges.

Material examined: [VENEZUELA. BolívAR: Mount Roraima] Roraima, XII-1909 (fl.), E.H.G. Ule 8591 (MG, NY). VENEZUELA. Bolívar: Monte Roraima, 11-II-2013 (fl., fr.), A. Melo 1106 (UFP).

23. Peperomia trinervula C. DC. in A. DC., Prod. 16(1): 420. 1869.

Figure $5 \mathrm{~h}$

Epiphytic herbs up to $50 \mathrm{~cm}$ tall, stems erect and pilose. It is characterized mainly by its orbicular to ovate or rarely elliptical leaves [(0.9) $1.2-2.4 \times(0.6) 1.2-2.8 \mathrm{~cm}]$ and axillary spikes, grouped in twos to threes (rarely solitary). From the shape of its leaves and campilodromous venation, it can be confused with $P$. pellucida, but $P$. trinervula has spikes grouped in twos or threes, rarely solitary, and its stems when fresh are usually reddish in color.

It occurs in Honduras, Venezuela, Colombia, Ecuador and Brazil, where it is known exclusively from Mount Roraima (Yuncker 1974, Callejas-Posada 1999, Steyermark \& Callejas-Posada 2003). It is found from 2,000 to $2,700 \mathrm{~m}$, which is similar to the citations for other countries, where it occurs in the areas of mountains, tepui and mountain ranges. $P$. rotundata var. trinervula is synonymy of $P$. trinervula, according Callejas \& Patiño (2011).

Material examined: [VENEZUELA. BolívAR: Mount Roraima] Roraima, I-1910 (fl.), Ule 8593 (MG). VENEZUELA. BolívAR: Mount Roraima, 13-II-2013 (fl.), A. Melo 1113 (UFP). 


\section{Acknowledgements}

The authors thank all the organizations that supported this research: CNPq; FACEPE (AMD 1262011); CAPES/PNADB, through the project "Estudos integrados da caracterização de plantas amazônicas: taxonomia, genética, química, citologia e biologia reprodutiva, com foco no Parque Nacional do Viruá, Estado de Roraima". The authors also thank the curators of the herbaria visited; the Instituto Nacional de Pesquisas da Amazônia (INPA); Regina Carvalho for the illustrations; and Dra. R. Forzza and Dra. M.R. Barbosa for comments.

\section{Literatura citada}

APG III. 2009. An update of the Angiosperm Phylogeny Group classification for the orders and families of flowering plants: APG III. Botanical Journal of the Linnean Society 161: 105-121.

Arias, T., Callejas-Posada, R. \& Bornstein, A. 2006. New combinations in Manekia, an earlier name for Sarcorhachis (Piperaceae). Novon 16: 205-208.

Burger, W. 1971. Family 41: Piperaceae. In: W. Burger (ed.). Flora Costaricensis. Field Museum of Natural History, Chicago, v. 35, pp. 5-218.

Callejas-Posada, R. 1999. Piperaceae. In: P.M. Jorgense \& S. Yánez-León (eds.). Catálogo de las plantas vasculares del Ecuador. Missouri Botanical Garden Press, St. Louis, pp. 785-805.

Callejas-Posada, R. 2008a. Piperaceae. In: D.C. Daly \& M. Silveira (eds.). Primeiro Catálogo da Flora do Acre, Brasil/ First Catalogue of flora of Acre, Brazil. EDUFAC, Rio Branco, pp. 296-305.

Callejas-Posada, R. 2008b. Piperaceae. In: O. Hokche, P.E. Berry \& O. Huber (eds.). Nuevo Catálogo de la Flora Vascular de Venezuela. Fundación Instituto Botánico de Venezuela, Caracas, pp. 546-557.

Callejas-Posada, R. \& Patiño, A. 2011. Piperaceae. In: A. Idárraga, R.C. Ortiz, R. Callejas-Posada \& M. Merello (eds.). Flora de Antioquia: catálogo de las plantas vasculares. Listado de las plantas vasculares del departamento de Antioquia. Universidad de Antioquia, Mendellín, v. 2, pp. 751-772.

Callejas-Posada, R., Görts-van Rijn, A.R.A. \& Steyermark, J.A. 2007. Piperaceae. In: V. Funk, T. Hollowell, P.E. Berry, C. Kelloff \& S.N. Alexander (eds.). Checklist of the Plants of the Guiana Shield [Venezuela: Amazonas, Bolivar, Delta Amacuro; Guyana, Surinam, French Guiana]. Contributions from the United States National Herbarium, v. 55, pp. 458-466.
Costa, M.A.S. \& Callejas-Posada, R. 1999. Piperaceae. In: J.E.L.S Ribeiro, M.J.G. Hopkins, A. Vicentini, C.A. Sothers, M.A.S. Costa, J.M. Brito, M.A.D. Souza, L.H.P. Martins, L.G. Lohmann, P.A.C.L. Assunção, E.C. Pereira, C.F. Silva, M.R. Mesquita \& L.C. Procópio, (eds.). Flora da Reserva Ducke: Guia de identificação das plantas vasculares de uma floresta de terra-firme na Amazônia Central. INPA, Manaus, pp. 181-187.

Dahlstedt, H. 1900. Studien Süd-und Central-Amerikanische Peperomien. Mit Besonderer Berücksichtigung der Brasiliannischien sippen. Kungl. Boktryckeriet. Norstedt \& Söner, P.A. Stockholm.

De Candolle, A.C.P. 1917. Piperaceae neotropicae. Notizblatt des Königl. Botanishen Gartens und Museums zu Berlin-Dahlen 6: 434-476.

Frenzke, L., Scheiris, E., Pino, G., Symmank, L., Goetghebeur, P. Neinhuis, C., Wanke, S. \& Samain, M. 2015. A revised infrageneric classification of the genus Peperomia (Piperaceae). Táxon 64: 424-444.

Görts-van Rijn, A.R.A. 2002. Piperaceae. In: S.A. Mori, G.Cremers, C.A. Gracie, J.J. Granville, S.V. Heald, M. Hoff \& J.D. Mitchell (eds.). Guide to the vascular plants of central French Guiana The New York Botanical Garden Press, New York, v. 2, pp. 574-584.

Görts-van Rijn, A.R.A. 2007. Piperaceae. In: M.J. JansenJacobs (ed.). Flora of the Guianas Royal Botanical Gardens, Kew, fasc. 24, pp. 15-163.

Guimarães, E.F. \& Giordano, L.S.C. 2004. Piperaceae do Nordeste brasileiro I: estado do Ceará. Rodriguésia 55: 21-46.

Guimarães, E.F., Carvalho-Silva, M., Monteiro, D., Medeiros, E. \& Queiroz, G.A. 2015. Piperaceae. In: Lista de Espécies da Flora do Brasil. Jardim Botânico do Rio de Janeiro, Rio de Janeiro. Available in http:// floradobrasil.jbrj.gov.br/jabot/floradobrasil/FB12609 (access in 4-IV-2015).

Harris, J. \& Harris, M.W. 2001. Plant identification terminology: an illustrated glossary. 2 ed. Spring Lake Publishing, Utah.

Heywood, V.H. 1978. Flowering plants of the world. 2 ed. Oxford University Press, Oxford.

Huber, O. 1988. Vegetacion y flora de Pantepui, Region Guayana. Acta Botanica Brasilica 1: 41-52.

IBGE. 2005. Mapa de vegetação do estado de Roraima. IBGE, Rio de Janeiro.

Hickey, L.J. 1974. Clasificación de la arquitectura de las hojas de dicotiledôneas. Boletin de La Sociedad Argentina de Botánica 16: 1-26.

Martínez, R.V. 1997. Flórula de las reservas biológicas de Iquitos, Perú. The Missouri Botanical Garden Press, St. Louis.

Mathieu, G. \& Callejas-Posada, R. 2006. New synonymies in the genus Peperomia Ruiz \& Pav. (Piperaceae)- an annotated checklist. Candollea 61: 331-363. 
Melo, A., Guimarães, E.F. \& Alves, M. 2014. Piperaceae do Parque Nacional do Viruá, Caracaraí, Roraima, Brasil. Rodriguésia 65: 455-470.

Miquel, F.A.W. 1852. Chloranthaceae et Piperaceae. In: C.F.P. Martius \& A.G. Eichler (eds.). Flora Brasiliensis Fleischer, Leipzing, v. 4, part. 1, pp. 5-222.

Mittermeier, R.A., Mittermeier, C.G., Brooks, T.M., Pilgrim, J.D., Konstant, W.R., Fonsseca, G.A.B. \& Kormos, C. 2003. Wilderness and biodiversity conservation. Proceedings of the National Academy of Sciences of the United States of America 100: 10309-10313.

Monteiro, D. \& Guimarães, E.F. 2008. Flora do Parque Nacional do Itatiaia- Brasil: Peperomia (Piperaceae). Rodriguésia 59: 161-195.

Mori, S.A., Mattos-Silva, L.A., Lisboa, G. \& Coradin, L. 1989. Manual de Manejo do Herbário Fanerogâmico. 2 ed. CEPLAC, Ilhéus.

Nee, M. 2004. Flora de la región del Parque Nacional Amboró, Bolivia, v. 2, Magnoliidae- HamamelidaeCaryophyllidae. Editorial FAN, Santa Cruz de la Sierra.

Prance, G.T. \& Johnson, D.M. 1992. Plant collections from the plateau of Serra do Aracá (Amazonas, Brazil) and their phytogeographic affinities. Kew Bulletin 47: 1-24.

Quijano-Abril, M.A., Callejas-Posada, R. \& MirandaEsquivel, D.R. 2006. Areas of endemism and distribution patterns for Neotropical Piper species (Piperaceae). Journal of Biogeography 33: 1266-1278.

Reis, N.J., Fraga, L.M., Faria, M.S.G. \& Almeida, M.E. 2003. Geologia do estado de Roraima. Géologie de la France 2-3-4: 121-134.

Samain, M.S., Mathieu, G., Wanke, S., Neinhuis, C. \& Goetghebeur, P. 2008. Verhuellia revisited-unravelling its intricate taxonomic history and a new subfamilial classification of Piperaceae. Taxon 57: 583-587.

Silva, J.M.C., Rylands, A.B. \& Fonseca, G.A.B. 2005. The fate of the Amazonian areas of endemism. Conservation Biology 19:689-694.

Steyermark, J.A. \& Callejas-Posada, R. 2003. Piperaceae. In: J.A. Steyermark, P.E. Berry \& B.H. Yatskievych (eds.). Flora of the Venezuela Guayana Missouri Botanical Garden Press, St. Louis, v. 7, pp. 681-738.

Sutherland, C.H.N. 2008. Catálogo de las plantas vasculares de Honduras. Espermatofitas. Secretaría de Recursos Naturales y Ambiente, Tegucigalpa.

Thiers, B. 2014. Index Herbariorum: A global directory of public herbaria and associated staff. World eletronic publication. New York Botanical Garden's Virtual Herbarium. Available in http://sweetgum.nybg.org/ih/ (access in 20-VI-2014).
Trelease, W. 1930. The geography of American peppers. Proceedings of the American Philosophical Society 69: 309-327.

Trelease, W. \& Yuncker, T.G. 1950. The Piperaceae of Northern South America. University of Illinois Press, Urbana, v. 2, pp. 442-838.

Veloso, H.P., Filho, A.L.R.R. \& Lima, J.C.A. 1991. Classificação da vegetação brasileira adaptada a um sistema universal. Rio de Janeiro, CDDI.

Wanke, S., Samain, M.S., Vanderschaeve, L., Mathieu, G., Goetghebeur, P. \& Neinhuis, C. 2006. Phylogeny of the genus Peperomia (Piperaceae) inferred from the trnK/matK region (cpDNA). Plant Biology 8: 93-102.

Yuncker, T.G. 1957. Piperaceae. In: A.A. Pulle (ed.). Flora of Suriname Royal Tropical Institute, Amsterdam, v. 1, pp. 218-290.

Yuncker, T.G. 1974. The Piperaceae of Brazil III. Peperomia: Taxa of uncertain status. Hoehnea 4: 71-413.

\section{List of exsicatae}

Almeida, S. \& Cordeiro, M. 743 (2), 577 (13). Barbosa, R.I. 130 (14). Batista, J. 1569 (10). Carvalho, F.A. 281 (8), 208 (19), 334 (20). Carvalho-Silva, M. 1033, 1034, 1044, 1045 (7). Fernandes, A. 3385 (8). Flores, A.S. 2197 (14). Hopkins, M.J.G. 874 (16). Huber, J. s.n. MG 1443 (2). Junk, W.J. s.n. INPA 109093, 1006 (14). Luteyn, J.L. 9768, 11311 (6). Marinho, T. 218 (19). Melo, A. 1108, 1111, 1112 (1), 1110 (3), 1021 (5), 1109 (6), 1033 (7), 1063 (11), 908, 934, 1012, 1022, 1029, 1030 (16), 909, 1032 (18), $1114(20), 1106$ (22), 1113 (23). Milliken, W. 9 (5), 241 (7), 289, 2150 (11). Nelson, B.W. 1546 (16). Pedrollo, C.T. 111 (11). Pessoa, E. 829 (5), 833, 854 (7), 853 (16), 852 (18). Pipoly, J.J. 6640, 6900 (2). Pires, J.M. 15122 (11), 16717, 16761 (16), 14523 (19). Prance, G.T. 13644 (2), 10825, 4157 (5), 9640, 10958, 28702 (7), 9642, 10182, 29203 (8), 4434, 10070, 11051 (11), 10008 (12), 9630, 10064 (13), 4183, 9257, 9388, 28701 (16), 9673, 13595 (17), 9983, 10772, 10959, 13517, 21359 (18), 9315, 10518, 13641, 19967, 23957, 29220 (19). Ratter, J.A. 5783 (16). Rodrigues, I.A. 882 (11). Rodrigues, W. 9869 (1). Rodrigues, W.A. 8356 (18). Rosa, N.A. 3270 (4), 3248 (12), 3229 (13), 3054 (16). Silva, E.S. 3193 (2), 3123 (19). Stannard, B.L. 733 (16). Steyermark, J.A. 58990 (3), 58732, 112585 (6). Ule, E.H.G. 9301 (2), 8594 (3), 8114 (4), 8113 (9), 8381 (12), 8590 (13), 8592 (15), 8589 (21), 8591 (22), 8593 (23). 